\title{
Diverse Roles of Inhibitor of Differentiation 2 in Adaptive Immunity
}

\author{
Lucille Rankin and Gabrielle T. Belz \\ Division of Molecular Immunology, Walter and Eliza Hall Institute of Medical Research, 1 G Royal Parade, Melbourne, \\ VIC 3052, Australia \\ Correspondence should be addressed to Gabrielle T. Belz, belz@wehi.edu.au
}

Received 18 September 2010; Accepted 15 January 2011

Academic Editor: Stuart Berzins

Copyright (๑) 2011 L. Rankin and G. T. Belz. This is an open access article distributed under the Creative Commons Attribution License, which permits unrestricted use, distribution, and reproduction in any medium, provided the original work is properly cited.

\begin{abstract}
The helix-loop-helix (HLH) transcription factor inhibitor of DNA binding 2 (Id2) has been implicated as a regulator of hematopoiesis and embryonic development. While its role in early lymphopoiesis has been well characterized, new roles in adaptive immune responses have recently been uncovered opening exciting new directions for investigation. In the innate immune system, Id2 is required for the development of mature natural killer (NK) cells, lymphoid tissue-inducer (LTi) cells, and the recently identified interleukin (IL)-22 secreting nonconventional innate lymphocytes found in the gut. In addition, Id 2 has been implicated in the development of specific dendritic cell (DC) subsets, decisions determining the formation of $\alpha \beta$ and $\gamma \delta$ T-cell development, NK T-cell behaviour, and in the maintenance of effector and memory CD8 ${ }^{+} \mathrm{T}$ cells in peripheral tissues. Here, we review the current understanding of the role of Id 2 in lymphopoiesis and in the development of the adaptive immune response required for maintaining immune homeostasis and immune protection.
\end{abstract}

\section{Introduction}

Protective immunity relies on the differentiation and maturation of lymphocytes into different cell lineages and the subsequent development of effector functions. Common lymphoid progenitors (CLPs) found in the bone marrow give rise to multiple different lineages including $\mathrm{B}, \mathrm{T}$, natural killer (NK) cells, NK T (NKT) cells, dendritic cells (DCs), and lymphoid tissue-inducer (LTi) cells. In the peripheral tissues, these lineages undergo further diversification as they mature.

Transcription factors play a key role in the commitment of lymphocytes to specific lineages. This is achieved through alteration of gene expression profiles in response to extrinsic signals (such as cytokines) that progressively restricts the developmental potential of these progenitors as they mature. Distinct transcriptional programs drive the proliferation, survival, and differentiation of lymphocytes into functionally different cell types. Dysregulation of these programs can often lead to inflammatory or autoimmune disease, cancers, and a compromised immune response. Thus, understanding how appropriate lineage-specific gene expression is achieved and maintained at steady state and in response to a pathogen challenge is important.

The basic Helix-Loop-Helix (bHLH) group of transcription factors, the E proteins, and their inhibitors, the inhibitor of DNA binding (Id) proteins, have been shown to play distinct and fundamental roles in the regulation of lymphocyte differentiation $[1,2]$.

\section{E Proteins}

E proteins are a class of transcription factors that consist of $\mathrm{HEB}, \mathrm{E} 2-2$, and the E2A gene products E12 and E47 that are produced by alternative splicing. They belong to a family of bHLH transcription factors that regulate gene expression of downstream targets by binding or associating with consensus E-box sequences in DNA [3]. These sequences are present in the regulatory regions of a number of lineage-specific genes such as CD4 in T cells and mannose-binding lectin 1 (Mbl1) in B cells [4]. Members of the bHLH family are defined by 
two conserved domains - the HLH domain regulates homoand/or heterodimerization while their basic domain plays a part in the binding of dimers to DNA [5].

The E protein, E2A, is essential for the development of committed B lymphocyte progenitors from CLPs (Table 1) $[6,7]$. E2A-deficient mice completely lack B-cells due to the requirement of E2A for pro-B-cell development into mature $\mathrm{B}$ cells prior to the IgH D-J rearrangement [8]. Interestingly, E2A regulates this transition in a dose-dependent manner which is reflected in an $\sim 50 \%$ reduction in the prevalence of pro-B cells in E2A $\mathrm{A}^{+/-}$mice $[7,8]$. However, E proteins do not function in isolation to control lymphocyte development. For example, the Early B-cell Factor (EBF)-1 and Pax5 transcription factors are also key determinants in B-cell differentiation and restrict cells at the pro-B-cell stage to adopt a B-cell fate $[9,10]$. Through biochemical and genetic analysis, it has been shown that E2A acts upstream of Pax5 and EBF during pro-B-cell development [11-13]. Thus, E2A is likely to be one of the earliest transcription factors that positively directs lymphocyte progenitors into the B-cell lineage.

E proteins are also involved in the stepwise developmental steps of $\mathrm{T}$ cells from $\mathrm{CD} 8^{-} \mathrm{CD} 4^{-}$double negative (DN) to $\mathrm{CD}^{+} \mathrm{CD}^{+}$double positive (DP) to single positive $\mathrm{CD}^{+} \mathrm{T}$ cytotoxic cells or $\mathrm{CD}^{+} \mathrm{T}$ helper cells $[14,15]$. These proteins have been shown to function together as heterodimers in T-cell development [15]. Thymocytes express multiple E proteins that have previously been thought to play complementary and compensatory roles during early T-cell differentiation. It has since been shown that HEB was uniquely required for the development of $\mathrm{CD} 8^{+} \mathrm{CD} 4^{+}$ double positive stage of $\mathrm{T}$-cell development and for the development of invariant natural killer $\mathrm{T}$ cells at an early progenitor stage [16]. Only relatively mild defects in T-cell development were observed in mice lacking either E2A or $\mathrm{HEB}$, but mice lacking both proteins or dominant negative HEB mutants had severe T-cell deficiencies due to a partial blockade of developing T cells at the DN stage of TCR $\beta$ gene rearrangement $[14,17-20]$. Thus, these studies demonstrate the existence of functional redundancy within the E protein family. A role of E proteins in regulating NKT cells had not been previously reported, but the E protein antagonist Id 2 has been implicated in regulating NKT cell homeostasis, suggesting that such a link may exist [10].

\section{Id Proteins}

The four Id proteins, Id1-4, are closely related in their HLH regions but differ in their tissue distributions [21, 22]. Id proteins dimerize with ubiquitously expressed E proteins through their highly conserved HLH motif. In contrast to E proteins, Id proteins lack the adjacent basic region necessary for DNA binding; thus, Id/E protein complexes inhibit E protein binding to DNA. Id proteins have many functions during early lymphopoiesis including B-cell specification and in directing the divergence of $\mathrm{NK}, \alpha \beta$, and $\gamma \delta \mathrm{T}$-cell lineages in early thymopoiesis (Figure 1, Table 1) [23-26]. Overexpression of Id1, Id2, or Id3 appears to have similar effects on lymphocyte development and block both B-cell and T-cell development [27-30]. The specific action of Id proteins in controlling lineage fate decisions depends on the ratio of Id to E proteins in developing cells. These levels can be modulated by extrinsic factors such as cytokines. In addition to E proteins, Id proteins have also been shown to interact with other transcription factors including the retinoblastoma protein ( $\mathrm{Rb})$, the ETS (E-twenty six), and Pax (Paired box) families to control cell differentiation [31-33].

\section{Id2, LTi Cells, and Lymphoid Tissue Development}

Id 2 is a critical regulator of multiple steps in development of lymphoid tissue and lymphocyte differentiation (outlined in Figures 1 and 2). Mice deficient in Id2 fail to develop lymph nodes, Peyer's patch, and other secondary lymphoid tissues including nasal-associated lymphoid tissues (NALTs) $[26,34]$. This is attributable to the lack of LTi cells (Figure 2) $[25,26]$.

LTi cells are essential for the development and organization of secondary lymphoid tissue and appear to play a key role in the maintenance and restoration of these tissues after destruction from disease [34-39]. LTi cells are classically defined as lineage negative $\left(\mathrm{CD}^{-} \mathrm{CD}^{-}{ }^{-} \mathrm{NK} 1.1^{-}\right.$ Gr. $\left.1^{-} \mathrm{CD} 11 \mathrm{c}^{-}\right) \mathrm{CD}_{4} 5^{+} \mathrm{c}-\mathrm{kit}^{\mathrm{low}} \mathrm{IL}-7 \mathrm{R}^{+} \mathrm{CD} 4^{+/-}$[38] and are thought to originate in the fetal liver from IL-7R ${ }^{+} \mathrm{Sca}-1^{\text {low }} \mathrm{C}-$ kit ${ }^{\text {low }}$ progenitors [40]. They depend on IL-7 signalling which acts through IL-7R leading to expansion of the LTi cell pool for lymphoid tissue organogenesis [41, 42]. Unexpectedly, LTi cells have been shown to produce IL-17 and/or IL-22 which are not required for lymph node formation but are critical for tissue remodelling [43, 44]. Both Id 2 and Ror $\gamma \mathrm{t}$ are required for induction of the signaling cascade involving IL-7R and LT $\alpha 1 \beta 2 / \mathrm{LT} \beta \mathrm{R}$ that eventually leads to the formation of lymph nodes and Peyer's patch. The formation of NALT, however, appears to be independent of Ror $\gamma t$ and LT $\beta R$ signaling $[26,34,45]$. Id2 is thought to regulate the differentiation of a common ancestor to LTi cells responsible for NALT, Peyer's patch, and lymph node organogenesis, and it is possible that Ror $\gamma \mathrm{t}$ is required further downstream to augment the signalling cascade. Studies of knockout and transgenic mice including retinoic acid-related orphan receptor (Ror) $\gamma \mathrm{t}^{-/-}\left(\right.$Ror $\left.\gamma \mathrm{t}^{-/-}\right), \mathrm{LT} \alpha^{-/-}, \mathrm{CXCR}^{-/-}$, IL$7 \mathrm{R}^{-/-}$, Janus Kinase (JAK) $3^{-/-}$, and Thymocyte selectionassociated high-mobility group box $(\mathrm{TOX})^{-/-}$mice have shown that in addition to Id2, Peyer's patch organogenesis and/or development of functional LTi cells also depend on these molecules [36, 46-49].

\section{Id2 and Innate Lymphoid Cells}

Innate lymphoid cells have recently emerged as a novel family of diverse hematopoietic effector cells that serve protective roles in immune responses to infectious organisms, in lymphoid tissue formation, and in the homeostasis of stromal cells. Collectively, they include NK cells and LTi cells in addition to nonclassical innate lymphoid cells that can 


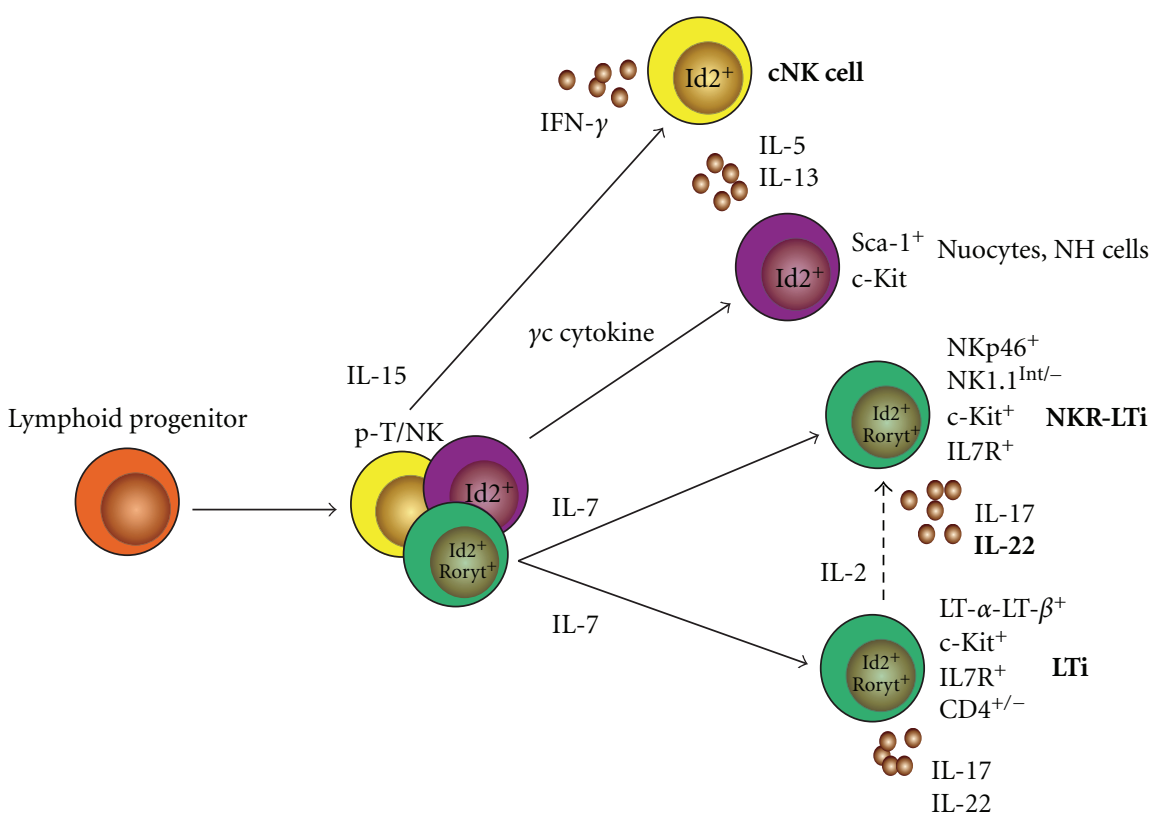

(a)

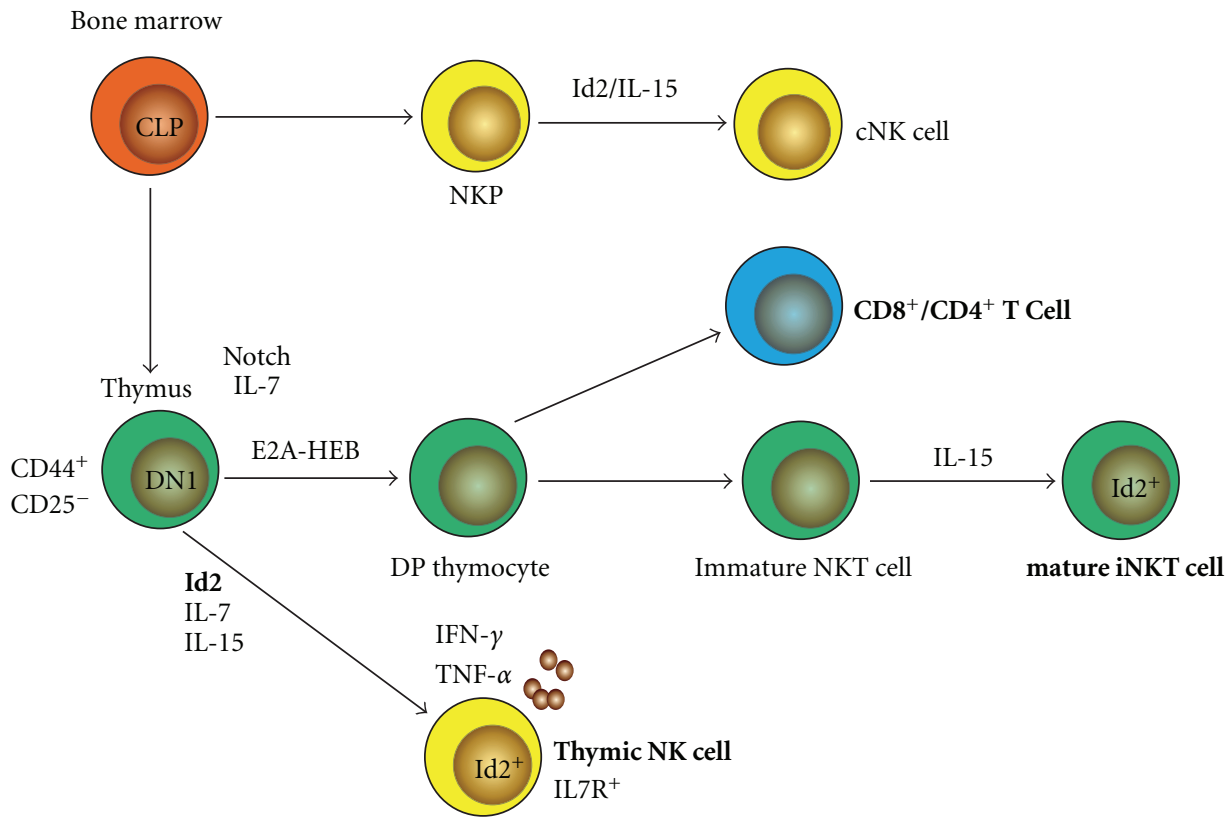

(b)

Figure 1: Regulation of NK, NKT, and innate lymphoid cells by Id2 during development. (a) Distinct subsets of lymphoid cells develop from hematopoietic cell precursors in the fetal liver in an Id2-dependent manner. Innate lymphoid cells can be divided into three main branches-(i) NK family, (ii) nuocytes/natural helper cells, and (iii) LTi/NKR-LTi cells that are dependent on Ror $\gamma$ t. The NK cell lineage is characterised by its spontaneous cytotoxicity and dependence on IL-15 for development. They develop from a bipotent T/NK cell precursor (pT/NK). The second group of cells contain the nuocytes and natural helper (NH) cells that facilitate B-cell responses. Although these cells depend on IL-7 and IL-2 for their development, they do not require Ror $\gamma$ t. The Ror $\gamma$ t-dependent branch includes LTi cells and innate lymphoid cells (including NKR-LTi cells) which produce the cytokines IL-17 and IL-22 and require IL-7 signaling. (b) Distinct subsets of lymphoid cells develop from a common lymphoid progenitor in the bone marrow of the adult mouse and upregulate or require Id 2 during development-(i) conventional NK cells (cNK), (ii) thymic NK cells, and (iii) NKT cells. NK cell progenitors upregulate Id 2 and receive IL-15 signals to become mature cNK cells. Thymic NK cells develop from a CD $44^{+} \mathrm{CD} 25^{-}$bipotent NK/T cell precursor where upregulation of Id 2 leads to an NK cell fate. These cells differ from cNK cells as they require both IL-7 and IL-15 signaling for development. They also have an enhanced ability to secrete TNF- $\alpha$ and IFN- $\gamma$ compared with cNK cells. NKT cells develop from T cell-committed double-positive (DP) thymocytes. During maturation of NKT cells in the thymus, Id2, together with an array of surface markers, is upregulated and culminates in NKT cells that are able to expand into the periphery. 
produce IL-5, IL-13, IL-17, and/or IL-22 (Figure 1). These lineages appear to be developmentally related requiring both the expression of Id 2 and cytokine signalling through the common $\gamma$-chain of the IL- 2 receptor. Functionally, these cells are quite heterogeneous (Figure 1(a)). For example, innate lymphoid cells that secrete the cytokines IL-5 and IL-13 are found in the adipose tissue associated with the mouse mesentery. These lin $^{-} \mathrm{c}-\mathrm{kit}^{+} \mathrm{sca}-1^{+}$cells have been termed "nuocytes" or natural helper cells reflecting their ability to provide help to the B1 cells [50]. Another class of nonclassical innate lymphoid cells are characterized by their expression of the NK cytotoxicity receptor, NKp46 (encoded by NCR1, the natural cytotoxicity receptor), and their ability to produce IL-22. They have recently been described as NKRLTi (NK receptor LTi) cells and are found predominantly in the intestinal lamina propria and Peyer's patches, as well as other mucosal compartments including the mesenteric lymph nodes [51-53]. They are dependent on the expression of Ror $\gamma$ t, have negligible levels of expression of NK1.1, and lack cytotoxic functions [53]. Although these cells are defined by their surface expression of NKp46, they do not depend on NKp46/NCR1 for their development [53]. NKR-LTi cells are more closely related to LTi cells than NK cells as both LTi and NKR-LTi lineages depend on Id 2 and Ror $\gamma$ t for their development, express c-kit, require IL-7 signaling, and secrete both IL-22 and IL-17 in response to IL-23 signaling through the IL-23R [52]. However, only a small fraction of NKR-LTi cells produce IL-17 [53, 54]. NKR-LTi cells are thought to play an important role in intestinal immunity as they significantly reduced in germ-free mice implying that signals from gut microflora drive their proliferation and survival $[53,55]$.

NK, LTi, and NKR-LTi cells depend on Id2 for their development, raising the possibility that they may stem from a common progenitor. In vitro, $\mathrm{CD} 4^{+} \mathrm{CD} 3^{-}$LTi cells were shown to differentiate into NK cells when cultured in IL-2, which lead to the proposal that this population contains progenitors of NK cells [38]. Further analysis has elucidated that the different Id2-dependent lineages found in the gut - LTi, NKR-LTi, and NK cells may develop along different pathways driven by specific cytokines. IL-7 is required for the proliferation of LTi and NKR-LTi cells which are dependent on Ror $\gamma$ t. In man, LTi and NKRLTi cells also depend on Ror $\gamma$ t (RORC in humans) for their development, while NK cells arise from $\mathrm{RORC}^{-} \operatorname{lin}^{-} \mathrm{c}-$ $\mathrm{kit}^{+} \mathrm{KLRG}^{+}{ }^{\mathrm{IL}-7 \mathrm{R}^{-}}$precursors [56]. It is IL-15 that drives the differentiation of NK precursors into mature NK cells via a Ror $\gamma$ t-independent pathway [56]. This is supported by the finding that a severe loss of mature NK cells occurs in IL-15 $5^{-/-}$mice, while LTi and gut NKR-LTi cell numbers are similar to those in wild-type mice [53]. Further lineage relationship analysis by inducible fate mapping of Ror $\gamma \mathrm{t}$ and in vitro cultures has shown that LTi and NKR-LTi cells stem from various subsets of foetal liver precursors based on Ror $\gamma$ t and $\alpha_{4} \beta_{7}$ expression, while NK cells arise from a Ror $\gamma \mathrm{t}^{-} \alpha_{4} \beta_{7}^{+}$progenitor [57]. Although LTi and NKRLTi cells share some characteristics with NK cells, they are developmentally and functionally distinct from NK cells. Precisely how LTi and NKR-LTi cells are related is a question that has received much attention in recent years. In vitro culture and in vivo transfer experiments have shown potential developmental plasticity between these two cell types. In this setting, Ror $\gamma \mathrm{t}^{+}$LTi-derived cells were able to upregulate NKp46 suggesting that LTi-like cells may be direct progenitors of NKR-LTi innate immune cells but not NK cells [58].

\section{Id 2 and NK Cells}

NK cells play an essential role in immune surveillance and defence against intracellular pathogens. They develop from CLPs in the bone marrow but also arise in the fetal liver and thymus from a more restricted T/NK cell progenitor. Here, the most immature but committed NK cell progenitors are defined by their expression of the IL-2/IL-15- $\beta$ receptor, CD122, and the absence of the $\mathrm{T}$ lymphocyte markers CD3, CD4, and CD8 [59, 60]. NK cells are dependent on the cytokine IL-15 for their proliferation and expansion into mature NK cells $[61,62]$. Several transcription factors including Ets-1, MEF-1, PU.1 [63-65], and Id2 are required for the development of the CD122 $2^{+} \mathrm{NK}$ lineage cells in the thymus and bone marrow-derived mature NK cells in the spleen $[25,26,66]$.

Although the development of T cells in the thymus is well defined, thymic NK cell development from a bipotent NK/T cell progenitor and the mechanisms regulating this pathway are less well studied. Analysis of NK/T cell progenitor activity in the fetal thymus demonstrated that the most immature thymocytes, the $\mathrm{CD} 44^{+} \mathrm{CD} 25^{-}$stage, contain NK development potential. This potential continues until cells reach the $\mathrm{CD} 44^{+} \mathrm{CD} 25^{+}$stage [76]. E2A-deficient mice have a partial block at the earliest stages of T-cell development in the thymus where NK/T cell progenitors arise $[14,17]$. In addition, $\mathrm{HEB}^{-/-}$and the transheterozygous $\mathrm{E} 2 \mathrm{~A}^{+/-} \mathrm{HEB}^{+/-}$ mice also display defects in the transition from the doublenegative to the double-positive stage of T-cell maturation $[15,74,75]$.

Id2-deficient mice display a severe reduction in thymusderived NK cells. It appears to play differential roles in NK cell development in the bone marrow and thymus. In the bone marrow, Id2 is not thought to be required for the development of committed NK progenitor cells but instead acts to regulate the formation of mature NK cells [25]. This maturation process is at least in part regulated by interactions between Id 2 and E2A activity as loss of both $\mathrm{Id} 2$ and E2A restores the development of mature NK cells. Despite this, these cells are impaired in their ability to emigrate from the bone marrow to spleen or in peripheral blood. Thus, overexpression of E-box proteins in this setting may contribute significantly to the lack of NK cell development in Id2-deficient mice [25].

The collaborative role of Id2, HEB, and IL-15 in NK cell development has been further investigated. It has been hypothesised that the cytokine IL-15 and Id 2 work synergistically to drive differentiation of NK cells in the thymus [77]. Id 2 is expressed in the thymic $\mathrm{CD} 1 \alpha^{-} \mathrm{CD} 5^{+}$precursor that has both NK- and T-cell potential. These cells could be 
TABLE 1: Phenotype of mouse strains lacking Id and E proteins.

\begin{tabular}{|c|c|c|}
\hline Gene & Phenotype & Reference \\
\hline Id 1 & $\begin{array}{l}\text { No significant phenotype in Id } 1^{-/-} \\
\mathrm{Id} 1^{-/-} / \mathrm{E} 2 \mathrm{~A}^{-/-} \text {knockout mice has improved postnatal survival compared to } \mathrm{E} 2 \mathrm{~A}^{-/-} \text {mice }\end{array}$ & {$[67]$} \\
\hline Id 2 & $\begin{array}{l}\text { Lack lymph nodes, Peyer's patch and NALT } \\
\text { Effects in memory CD8 }{ }^{+} \text {T cell maintenance } \\
\text { Lack NK cells } \\
\text { Lack CD } 8 \alpha^{+} \text {DCs and Langerhans cells }\end{array}$ & $\begin{array}{l}{[26,34,68,} \\
69]\end{array}$ \\
\hline Id 3 & $\begin{array}{l}\text { Overexpression promotes NK cell development } \\
\text { Defects in B and T cells } \\
\text { Increase in } \gamma \delta \mathrm{T} \text { cell production }\end{array}$ & {$[70][71]$} \\
\hline Id 4 & $\begin{array}{l}\text { Smaller brain size } \\
\text { Block in differentiation of neural progenitors } \\
\text { Role in lymphopoiesis not yet investigated }\end{array}$ & {$[72]$} \\
\hline E2A & $\begin{array}{l}\text { Increased number of NK cells } \\
\text { Ablated B-cell development }\end{array}$ & {$[6]$} \\
\hline E2-2 & Lack plasmacytoid DCs & {$[73]$} \\
\hline HEB & Disruption of $\alpha \beta$ thymopoiesis from the DN to DP stage & {$[15,74,75]$} \\
\hline
\end{tabular}

expanded and differentiated into mature NK cells in the presence of IL-15 [77]. In this setting, induction of Id 2 promoted NK cell development but impaired T-cell differentiation. This pathway could be reversed by coexpression of HEB suggesting that the balance between Id 2 and HEB in the early progenitor cells is an important factor in determining NK/T cell fate. Indeed overexpression of HEB leads to commitment to the T-cell lineage, while high levels of expression of Id2 commit progenitors to an IL-15 responsive NK-cell lineage [77].

\section{Id2 and Natural Killer T Cells}

Natural Killer T (NKT) cells are defined by their expression of CD4, NK1.1, and CD44. NK T cells have characteristics of both $\mathrm{CD}^{+} / \mathrm{CD} 4^{+} \mathrm{T}$ cells and NK cells [78]. They can be divided into three main subsets, the most studied being the invariant $\mathrm{V} \alpha 14 \mathrm{~T}$-cell receptor expressing NKT (iNKT) cell population [79]. These cells also use several transcription factors such as Id2 and cytokines that are also key regulators of NK and T-cell differentiation (Figure 1(b)). Similar to NK cells, Id2 is highly expressed in NKT cells compared with naïve $\mathrm{CD}^{+} \mathrm{T}$ cells suggesting it also plays a role in NKT cell development. Indeed, it has been found that Id2deficient NKT cells have reduced expression of the homing receptor, CXCR6, and the proapoptotic molecule, Bim [80]. Regulation of these two molecules by Id 2 and $\mathrm{E}$ protein transcription factors appears to be important in regulating the survival and accumulation of NKT cells in the liver [10].

\section{Id2 and DCs}

DCs are professional antigen-presenting cells that act as sentinels in the body and protect against pathogen infection. DCs originate from hemopoietic precursors and differentiate into a variety of subsets that have been defined based on their anatomical location, phenotypic appearance, and their capacity to take up, process, and present antigens. DCs are divided into two major populations-namely the conventional DCs (cDCs), which are highly efficient in taking up and presenting antigens, and plasmacytoid DCs (pDCs), that produce abundant amounts of interferon (IFN) $-\alpha$ in response to viral infection $[81,82]$.

Several transcription factors including Id2, interferon regulatory factors (IRFs)-2, 4, and 8, Stat3, Gfi-1, and PU-1 have been implicated in the development and/or homeostasis of DC populations [83-89]. Precisely where and how these transcription factors act to define DC subset specification is less clear. All DC subsets arise from Flt3Rexpressing myeloid or lymphoid precursors and depend on the expression of the transcription factors PU.1 and IRF-8 [89-93]. Recently, Id and E proteins have been found to be critical for lineage specification of $\mathrm{cDCs}$ and pDCs (Figure 2). pDC fate is specifically determined by E2-2 (Tcf4) which also induces the expression of the transcription factors SpiB, IRF-8, and IRF-7 required for their function [73, 94, 95]. Furthermore, ectopic expression of Id 2 in multipotent progenitors prevented $\mathrm{pDC}$, but not $\mathrm{cDC}$, development presumably by inhibiting E2-2 function [96]. cDC lineages do not depend on E2-2 but instead rely on IRF-8, Id2, and the basic leucine zipper transcription factor, ATF-like 3 (or Batf3), for subset specification [68, 84, 97]. During DC differentiation, Id 2 expression is upregulated and this effect is strongly enhanced by the addition of TGF- $\beta$, suggesting that Id 2 is crucial for the development of certain DC subsets [68]. Mice that lack Id 2 fail to develop CD $8 \alpha^{+}$DCs, LCs, and the more recently described $\mathrm{CD} 103^{+}$DC subset which shares many features with CD $8 \alpha^{+}$DCs [68]. Complementing these findings, mice deficient in TGF- $\beta$ lack LCs suggesting a link between TGF- $\beta$ induction and Id2. Intriguingly, mice that lack the transcription factors IRF-8, Id2, or Batf3 present with similar defects- that is, they have significantly reduced 


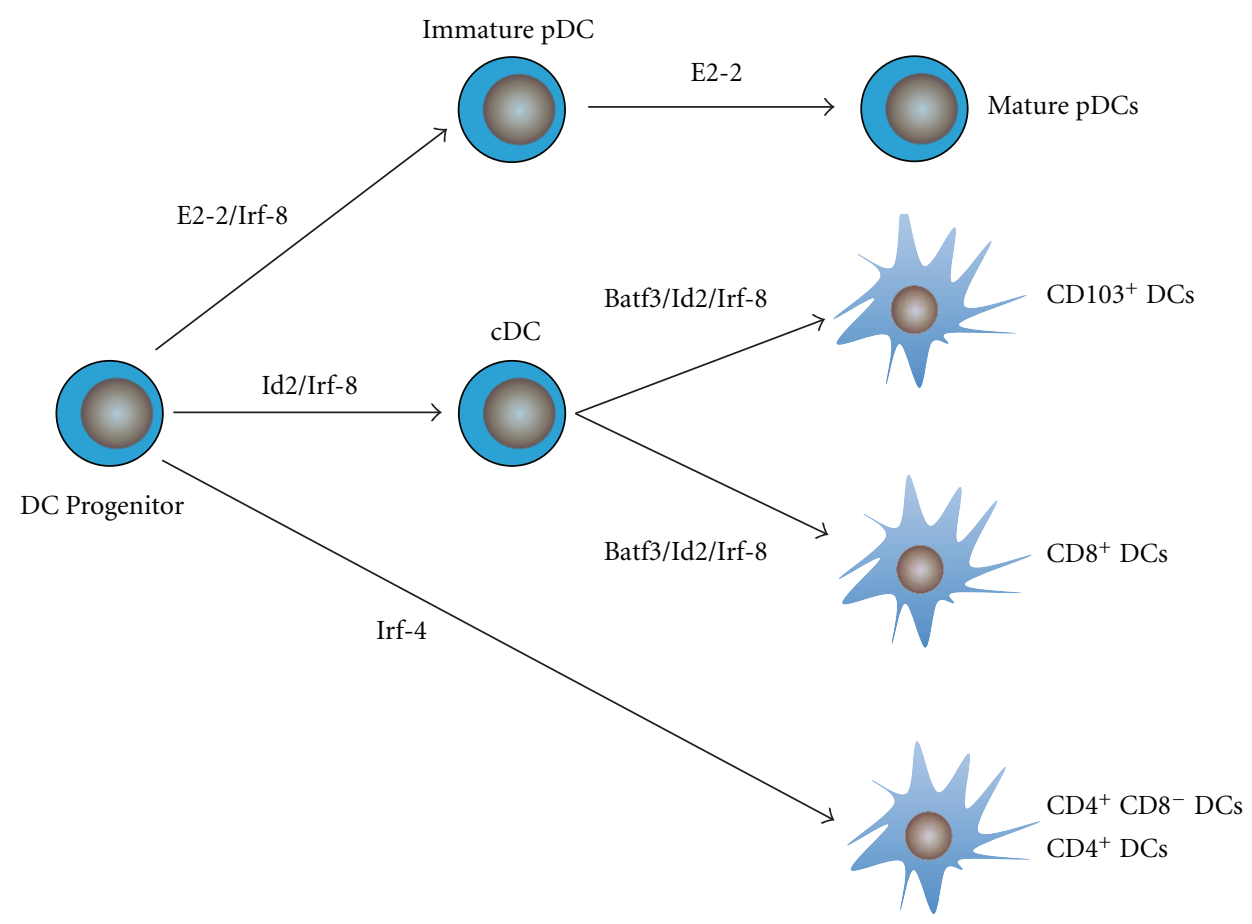

Figure 2: Transcription factors involved in DC development. Several transcription factors are required for the development of the common DC progenitor into functionally and phenotypically distinct subsets. IRF-8 is required for the development of both pDC and some cDC populations including the $\mathrm{CD}_{103}{ }^{+}$and $\mathrm{CD} 8 \alpha^{+}$DC subsets. The bHLH protein E2-2 specifies the pDC lineage and is also required for the maintenance of mature pDC identity. During differentiation, Id2 is induced in all conventional DC subsets and binds E2-2 to prevent their development into pDCs. The transcription factor Batf3 is essential for the development of CD103 ${ }^{+}$DCs; however, precursors of CD8 $\alpha^{+}$DCs can develop in its absence although their survival is impaired. Other DC (CD4 ${ }^{+}$and $\left.\mathrm{CD} 4^{-} \mathrm{CD} 8^{-} \mathrm{DCs}\right)$ subsets depend more specifically on IRF-4 for their development.

numbers of $\mathrm{CD} 8 \alpha^{+}$and $\mathrm{CD} 103^{+}$DCs. This initially suggests that these DC subsets may be highly related. The exact action of each of these transcription factors in regulating the steps involved in DC subset differentiation is not yet defined. It is also not known how different $\mathrm{E}$ proteins are induced and regulated in DC subsets although the balance between Id 2 and $\mathrm{E}$ proteins is likely to be important in subset specification.

\section{Id2 and Peripheral T-Cell Differentiation}

$\mathrm{CD}^{+}$and $\mathrm{CD}^{+}{ }^{+} \mathrm{T}$ cells are crucial for clearance of infection by viruses, intracellular bacteria, and protozoan parasites. On recognition of foreign pathogens, naïve $\mathrm{T}$ cells quickly become activated and develop effector functions that enable them to eliminate these pathogens. The initial phase of expansion and acquisition of effector function is followed by a contraction phase where the majority of the reactive $\mathrm{T}$ cells undergo programmed cell death leaving behind a small, but relatively stable, population of memory cells. These cells are poised to quickly respond to a second encounter with the same pathogen. This differentiation process is tightly regulated by a number of transcription factors. T-bet, eomesodermin (eomes), B lymphoycyte-induced maturation protein-1 (Blimp1; also called PRDI-BF1 in humans and encoded by the Prdm1 gene), Id2, and Bcl-6 appear to be important for the generation and maintenance of $\mathrm{CD} 8^{+} \mathrm{T}$ cell memory $[69,98-100]$, reviewed in $[101,102]$. In CD4 ${ }^{+}$ T cells, T-bet, GATA-3, IRF-4, ROR $\gamma$ t, and Foxp3 regulate differentiation of the different lineages (reviewed in [103]).

Id2 has recently been found to play a role in the maintenance of effector and memory $\mathrm{CD} 8^{+} \mathrm{T}$ cells despite the fact that Id $2^{-/-}$mice appear to have normal development of their T-cell compartment $[26,69]$. Id2 expression is low in naïve $\mathrm{CD}^{+} \mathrm{T}$ cells, but it is markedly upregulated in antigen-specific $\mathrm{T}$ cells following infection in vivo. Mice deficient in Id2 appear to lack effector memory, but not central memory, $\mathrm{CD} 8^{+} \mathrm{T}$ cells, but the mechanism by which this arises is unclear. However, when Id $2^{-/-}$mice are infected with Listeria monocytogenes, the $\mathrm{CD}^{+}{ }^{+} \mathrm{T}$-cell response is strongly impaired even though the antigen-specific $\mathrm{T}$ cells appear to proliferate normally during the immune response [69]. It is known that Id proteins contribute to the regulation of cell cycle progression. Thus, it has been proposed that lack of Id2 in T cells leads to enhanced apoptosis by increased expression of Bim and CTLA- 4 and reduced expression of Bcl-2 [69]. Whether apoptotic proteins are directly regulated by Id2 during differentiation or, alternately, whether cell death is the outcome of cell cycle arrest that occurs in the absence of Id2 (perhaps a consequence of disregulated bHLH partners) is still unclear. 
The regulation of $\mathrm{CD} 4^{+} \mathrm{T}$-cell differentiation into effector and memory populations by Id 2 has not been extensively investigated. Id2-deficient mice exhibit features of a Th2 bias with increased IgG1 and IgE and enhanced expression of Th2-related genes such as IL-4. However, this phenotype does not appear to be an intrinsic feature of Id2 deficiency in $\mathrm{CD}^{+} \mathrm{T}$ cells as it does not persist in T cells in vitro [104]. One possible explanation for the dysregulation of Th1/Th2 balance in the $\mathrm{Id} 2^{-/-}$mice is that the reduced number of CD $8 \alpha^{+}$DCs and IL-12 associated with this DC type in these mice may limit the generation of Th1 type responses [104]. Further investigations will be necessary to elucidate the specific actions of $\mathrm{Id} 2$ in $\mathrm{CD}^{+}$and $\mathrm{CD}^{+} \mathrm{T}$ cells.

\section{Id2 Effects outside the Immune System}

In addition to the pronounced effects Id2 has on the development of the immune system, it also plays diverse roles in other cell types pointing to the importance of this transcription factor in development. For example, Id 2 has been implicated in red blood cell development through its interactions with the transcription factor PU.1 and repression of Rb protein $[24,32,105]$. Outside the hematopoietic system, Id 2 is critical for the development of mammary glands. Id2-deficient female mice show lactation defects associated with impaired lobuloalveolar development, while males have significantly reduced spermatogenesis $[106,107]$. Similarly, Id2-induced cell cycle arrest prevents differentiation of enterocyte precursors during embryogenesis, and Id2 expression in distal tip lung epithelial multipotent precursors is essential for normal lung formation and remodelling [108].

\section{Conclusions and Future Directions}

In the past 10 years, major steps forward have been made in understanding how Id and E proteins work to regulate lymphopoiesis. It has long been known that the generation of adaptive immunity requires a diverse set of lymphocytes with both distinct and overlapping functions. Id 2 plays an important role in defining the differentiation fate of peripheral lymphocytes and in their responses to infection. Despite this progress, several important questions defining the role of Id2 in lymphopoiesis remain unanswered. Although a number of immune cell lineages require Id 2 for differentiation, it is unclear precisely where Id2 acts to define fate decisions. Furthermore, how extrinsic signals such as cytokines regulate Id 2 and the balance of E proteins has not been investigated. It is clear that Id2 is involved in the development of DCs, $\mathrm{NK}, \mathrm{LTi}$, and $\mathrm{CD}^{-} \mathrm{NKp} 46^{+}$cells. However, it remains to be elucidated how these Id2-dependent lineages are developmentally related and how Id 2 regulates their differentiation at a molecular level. For example, which cytokines induce Id2 expression and what are the downstream targets that control lineage fate decisions? Furthermore, how Id 2 regulates the balance between effector/memory T-cell generation and differentiation plasticity is poorly characterized. It is likely that detailed elucidation of the functions of Id2 and its regulation will lead to a deeper understanding of how this transcription factor contributes to the overall process of immune homeostasis and protective immunity.

\section{Abbreviations}

Blimp1: B lymphocyte-induced maturation protein-1

CLP: Common lymphoid precursor

DCs: Dendritic cell(s)

cDCs: Conventional dendritic cell(s)

cNK: $\quad$ Conventional NK cell(s)

pDCs: Plasmacytoid dendritic cell(s)

FLT3R: Fms-like tyrosine kinase 3 receptor

GALT: Gut-associated lymphoid tissues

HLH: Helix-loop-helix; bHLH, basic

helix-loop-helix

Id: Inhibitor of DNA binding

IFN: Interferon regulatory factor

LTi: $\quad$ Lymphoid tissue inducer cell(s)

NALT: Nasal-associated lymphoid tissue

NK: $\quad$ Natural killer cell(s)

NKR-LTi: NK receptor LTi cell(s)

NKT: $\quad$ NK T cell(s)

Rb: Retinoblastoma

Ror $\gamma$ t: $\quad$ Retinoic acid-related orphan receptor $\gamma \mathrm{t}$.

\section{Acknowledgments}

This work is supported by the National Health and Medical Research Council of Australia, the Sylvia and Charles Viertel Foundation (Australia), and the Howard Hughes Medical Institute (USA).

\section{References}

[1] M. E. Massari and C. Murre, "Helix-loop-helix proteins: regulators of transcription in eucaryotic organisms," Molecular and Cellular Biology, vol. 20, no. 2, pp. 429-440, 2000.

[2] Y. Yokota, "Id and development," Oncogene, vol. 20, no. 58, pp. 8290-8298, 2001.

[3] C. Murre, P. S. McCaw, H. Vaessin et al., "Interactions between heterologous helix-loop-helix proteins generate complexes that bind specifically to a common DNA sequence," Cell, vol. 58, no. 3, pp. 537-544, 1989.

[4] M. Sigvardsson, D. R. Clark, D. Fitzsimmons et al., "Early Bcell factor, E2A, and Pax-5 cooperate to activate the early B cell-specific mb-1 promoter," Molecular and Cellular Biology, vol. 22, no. 24, pp. 8539-8551, 2002.

[5] C. Murre, P. S. McCaw, and D. Baltimore, "A new DNA binding and dimerization motif in immunoglobulin enhancer binding, daughterless, MyoD, and myc proteins," Cell, vol. 56, no. 5, pp. 777-783, 1989.

[6] G. Bain, E. C. R. Maandag, D. J. Izon et al., "E2A proteins are required for proper $b$ cell development and initiation of immunoglobulin gene rearrangements," Cell, vol. 79, no. 5, pp. 885-892, 1994.

[7] Y. Zhuang, P. Soriano, and H. Weintraub, "The helix-loophelix gene E2A is required for B cell formation," Cell, vol. 79, no. 5, pp. 875-884, 1994.

[8] Y. Zhuang, P. Cheng, and H. Weintraub, "B-lymphocyte development is regulated by the combined dosage of three 
basic helix-loop-helix genes, E2A, E2-2, and HEB," Molecular and Cellular Biology, vol. 16, no. 6, pp. 2898-2905, 1996.

[9] S. L. Nutt, B. Heavey, A. G. Rolink, and M. Busslinger, "Commitment to the B-lymphoid lineage depends on the transcription factor Pax5," Nature, vol. 401, no. 6753, pp. 556-562, 1999.

[10] L. A. Monticelli, Y. Yang, J. Knell et al., "Transcriptional regulator Id 2 controls survival of hepatic NKT cells," Proceedings of the National Academy of Sciences of the United States of America, vol. 106, no. 46, pp. 19461-19466, 2009.

[11] M. O'Riordan and R. Grosschedl, “Coordinate regulation of $B$ cell differentiation by the transcription factors EBF and E2A," Immunity, vol. 11, no. 1, pp. 21-31, 1999.

[12] B. L. Kee and C. Murre, "Induction of early B cell factor (EBF) and multiple B lineage genes by the basic helix-loop-helix transcription factor E12," Journal of Experimental Medicine, vol. 188, no. 4, pp. 699-713, 1998.

[13] M. Sigvardsson, M. O’Riordan, and R. Grosschedl, “EBF and E47 collaborate to induce expression of the endogenous immunoglobulin surrogate light chain genes," Immunity, vol. 7, no. 1, pp. 25-36, 1997.

[14] G. Bain, M. W. Quong, R. S. Soloff, S. M. Hedrick, and C. Murre, "Thymocyte maturation is regulated by the activity of the helix-loop-helix protein, E47," Journal of Experimental Medicine, vol. 190, no. 11, pp. 1605-1616, 1999.

[15] R. J. Barndt, M. Dai, and Y. Zhuang, "Functions of E2A-HEB heterodimers in T-cell development revealed by a dominant negative mutation of HEB," Molecular and Cellular Biology, vol. 20, no. 18, pp. 6677-6685, 2000.

[16] L. M. D'Cruz, J. Knell, J. K. Fujimoto, and A. W. Goldrath, "An essential role for the transcription factor HEB in thymocyte survival, Tcra rearrangement and the development of natural killer T cells," Nature Immunology, vol. 11, no. 3, pp. 240-249, 2010.

[17] G. Bain, I. Engel, E. C. R. Maandag et al., "E2A deficiency leads to abnormalities in $\alpha \beta$ T-cell development and to rapid development of T-cell lymphomas," Molecular and Cellular Biology, vol. 17, no. 8, pp. 4782-4791, 1997.

[18] R. Barndt, M. F. Dai, and Y. Zhuang, "A novel role for HEB downstream or parallel to the pre-TCR signaling pathway during $\alpha \beta$ thymopoiesis," Journal of Immunology, vol. 163, no. 6, pp. 3331-3343, 1999.

[19] R. J. Barndt, M. Dai, and Y. Zhuang, "Functions of E2A-HEB heterodimers in T-cell development revealed by a dominant negative mutation of HEB," Molecular and Cellular Biology, vol. 20, no. 18, pp. 6677-6685, 2000.

[20] J. Wojciechowski, A. Lai, M. Kondo, and Y. Zhuang, "E2A and HEB are required to block thymocyte proliferation prior to pre-TCR expression," Journal of Immunology, vol. 178, no. 9, pp. 5717-5726, 2007.

[21] J. D. Norton, R. W. Deed, G. Craggs, and F. Sablitzky, "Id helix-loop-helix proteins in cell growth and differentiation," Trends in Cell Biology, vol. 8, no. 2, pp. 58-65, 1998.

[22] K. Langlands, X. Yin, G. Anand, and E. V. Prochownik, "Differential interactions of Id proteins with basic-helix-loophelix transcription factors," Journal of Biological Chemistry, vol. 272, no. 32, pp. 19785-19793, 1997.

[23] M. W. Quong, W. J. Romanow, and C. Murre, "E protein function in lymphocyte development," Annual Review of Immunology, vol. 20, pp. 301-322, 2002.

[24] M. Ji, H. Li, H. C. Suh, K. D. Klarmann, Y. Yokota, and J. R. Keller, "Id2 intrinsically regulates lymphoid and erythroid development via interaction with different target proteins," Blood, vol. 112, no. 4, pp. 1068-1077, 2008.
[25] M. D. Boos, Y. Yokota, G. Eberl, and B. L. Kee, "Mature natural killer cell and lymphoid tissue-inducing cell development requires Id2-mediated suppression of E protein activity," Journal of Experimental Medicine, vol. 204, no. 5, pp. 11191130, 2007.

[26] Y. Yokota, A. Mansouri, S. Mori et al., "Development of peripheral lymphoid organs and natural killer cells depends on the helix-loop-helix inhibitor Id2," Nature, vol. 397, no. 6721, pp. 702-706, 1999.

[27] M. A. Morrow, E. W. Mayer, C. A. Perez, M. Adlam, and G. Siu, "Overexpression of the helix-loop-helix protein Id2 blocks T cell development at multiple stages," Molecular Immunology, vol. 36, no. 8, pp. 491-503, 1999.

[28] X. H. Sun, "Constitutive expression of the Id1 gene impairs mouse b cell development," Cell, vol. 79, no. 5, pp. 893-900, 1994.

[29] D. Kim, X. C. Peng, and X. H. Sun, "Massive apoptosis of thymocytes in T-cell-deficient Id1 transgenic mice," Molecular and Cellular Biology, vol. 19, no. 12, pp. 8240-8253, 1999.

[30] B. L. Kee and C. Murre, "Transcription factor regulation of B lineage commitment," Current Opinion in Immunology, vol. 13, no. 2, pp. 180-185, 2001.

[31] E. C. Roberts, R. W. Deed, T. Inoue, J. D. Norton, and A. D. Sharrocks, "Id helix-loop-helix proteins antagonize Pax transcription factor activity by inhibiting DNA binding," Molecular and Cellular Biology, vol. 21, no. 2, pp. 524-533, 2001.

[32] A. Iavarone, P. Garg, A. Lasorella, J. Hsu, and M. A. Israel, "The helix-loop-helix protein Id-2 enhances cell proliferation and binds to the retinoblastoma protein," Genes and Development, vol. 8, no. 11, pp. 1270-1284, 1994.

[33] P. R. Yates, G. T. Atherton, R. W. Deed, J. D. Norton, and A. D. Sharrocks, "Id helix-loop-helix proteins inhibit nucleoprotein complex formation by the TCF ETS-domain transcription factors," The EMBO Journal, vol. 18, no. 4, pp. 968-976, 1999.

[34] S. Fukuyama, T. Hiroi, Y. Yokota et al., "Initiation of NALT organogenesis is independent of the IL-7R, LT $\beta$, and NIK signaling pathways but requires the Id 2 gene and CD ${ }^{-} \mathrm{CD}^{+}{ }^{+} \mathrm{CD} 45^{+}$cells," Immunity, vol. 17, no. 1, pp. 31-40, 2002.

[35] D. R. Withers, M.-Y. Kim, V. Bekiaris et al., "The role of lymphoid tissue inducer cells in splenic white pulp development," European Journal of Immunology, vol. 37, no. 11, pp. 3240-3245, 2007.

[36] D. Finke, H. Acha-Orbea, A. Mattis, M. Lipp, and J. P. Kraehenbuhl, " $\mathrm{CD} 4^{+} \mathrm{CD}^{-}$cells induce Peyer's patch development: role of $\alpha 4 \beta 1$ integrin activation by CXCR5," Immunity, vol. 17, no. 3, pp. 363-373, 2002.

[37] U. Hofer and R. F. Speck, "Disturbance of the gut-associated lymphoid tissue is associated with disease progression in chronic HIV infection," Seminars in Immunopathology, vol. 31, no. 2, pp. 257-266, 2009.

[38] R. E. Mebius, P. Rennert, and I. L. Weissman, "Developing lymph nodes collect $\mathrm{CD} 4^{+} \mathrm{CD} 3^{-} \mathrm{LT} \beta^{+}$cells that can differentiate to APC, NK cells, and follicular cells but not T or B cells," Immunity, vol. 7, no. 4, pp. 493-504, 1997.

[39] E. Scandella, B. Bolinger, E. Lattmann et al., "Restoration of lymphoid organ integrity through the interaction of lymphoid tissue-inducer cells with stroma of the T cell zone," Nature Immunology, vol. 9, no. 6, pp. 667-675, 2008.

[40] R. E. Mebius, T. Miyamoto, J. Christensen et al., "The fetal liver counterpart of adult common lymphoid progenitors gives rise to all lymphoid lineages, $\mathrm{CD} 45^{+} \mathrm{CD} 4^{+} \mathrm{CD}^{-}$cells, 
as well as macrophages," Journal of Immunology, vol. 166, no. 11, pp. 6593-6601, 2001.

[41] S. Chappaz and D. Finke, "The IL-7 signaling pathway regulates lymph node development independent of peripheral lymphocytes," Journal of Immunology, vol. 184, no. 7, pp. 3562-3569, 2010.

[42] S. Schmutz, N. Bosco, S. Chappaz et al., "Cutting edge: IL7 regulates the peripheral pool of adult ROR $\gamma^{+}$lymphoid tissue inducer cells," Journal of Immunology, vol. 183, no. 4, pp. 2217-2221, 2009.

[43] W. Ouyang, J. K. Kolls, and Y. Zheng, "The biological functions of T helper 17 cell effector cytokines in inflammation," Immunity, vol. 28, no. 4, pp. 454-467, 2008.

[44] H. Takatori, Y. Kanno, W. T. Watford et al., "Lymphoid tissue inducer-like cells are an innate source of IL-17 and IL-22," Journal of Experimental Medicine, vol. 206, no. 1, pp. 35-41, 2009.

[45] G. Ebertl and D. R. Litman, "Thymic origin of intestinal $\alpha \beta$ T cells revealed by fate mapping of ROR $\gamma \mathrm{t}^{+}$cells," Science, vol. 305, no. 5681, pp. 248-251, 2004.

[46] S. Adachi, H. Yoshida, K. Honda et al., "Essential role of IL-7 receptor $\alpha$ in the formation of Peyer's patch anlage," International Immunology, vol. 10, no. 1, pp. 1-6, 1998.

[47] Z. Sun, D. Unutmaz, Y. R. Zou et al., "Requirement for ROR $\gamma$ in thymocyte survival and lymphoid organ development," Science, vol. 288, no. 5475, pp. 2369-2373, 2000.

[48] P. De Togni, J. Goellner, N. H. Ruddle et al., "Abnormal development of peripheral lymphoid organs in mice deficient in lymphotoxin," Science, vol. 264, no. 5159, pp. 703-707, 1994.

[49] P. Aliahmad, B. de la Torre, and J. Kaye, "Shared dependence on the DNA-binding factor TOX for the development of lymphoid tissue-inducer cell and NK cell lineages," Nature Immunology, vol. 11, no. 10, pp. 945-952, 2010.

[50] D. R. Neill, S. H. Wong, A. Bellosi et al., "Nuocytes represent a new innate effector leukocyte that mediates type2 immunity," Nature, vol. 464, no. 7293, pp. 1367-1370, 2010.

[51] N. Satoh-Takayama, C. A. J. Vosshenrich, S. Lesjean-Pottier et al., "Microbial flora drives interleukin 22 production in intestinal $\mathrm{NKp} 46^{+}$cells that provide innate mucosal immune defense," Immunity, vol. 29, no. 6, pp. 958-970, 2008.

[52] C. Luci, A. Reynders, I. I. Ivanov et al., "Influence of the transcription factor ROR $\gamma \mathrm{t}$ on the development of $\mathrm{NKp} 46^{+}$ cell populations in gut and skin," Nature Immunology, vol. 10 , no. 1 , pp. 75-82, 2009.

[53] S. L. Sanos, V. L. Bui, A. Mortha et al., "ROR $\gamma$ t and commensal microflora are required for the differentiation of mucosal interleukin 22-producing NKp $46^{+}$cells," Nature Immunology, vol. 10, no. 1, pp. 83-91, 2009.

[54] H. Takatori, Y. Kanno, W. T. Watford et al., "Lymphoid tissue inducer-like cells are an innate source of IL-17 and IL-22," Journal of Experimental Medicine, vol. 206, no. 1, pp. 35-41, 2009.

[55] S. Buonocore, P. P. Ahern, H. H. Uhlig et al., "Innate lymphoid cells drive interleukin-23-dependent innate intestinal pathology," Nature, vol. 464, no. 7293, pp. 1371-1375, 2010.

[56] N. Satoh-Takayama, S. Lesjean-Pottier, P. Vieira et al., "IL7 and IL-15 independently program the differentiation of intestinal $\mathrm{CD}^{-} \mathrm{NKp}^{+} 6^{+}$cell subsets from Id2-dependent precursors," Journal of Experimental Medicine, vol. 207, no. 2, pp. 273-280, 2010.

[57] S. Sawa, M. Cherrier, M. Lochner et al., "Lineage relationship analysis of ROR $\gamma \mathrm{t}^{+}$innate lymphoid cells," Science, vol. 330, no. 6004, pp. 665-669, 2010.
[58] C. Vonarbourg, A. Mortha, V. L. Bui et al., "Regulated expression of nuclear receptor $\mathrm{ROR} \gamma \mathrm{t}^{+}$confers distinct functional fates to NK cell receptor-expressing $\mathrm{ROR} \gamma \mathrm{t}^{+}$innate lymphocytes," Immunity, vol. 33, no. 5, pp. 736-751, 2010.

[59] E. E. Rosmaraki, I. Douagi, C. Roth, F. Colucci, A. Cumano, and J. P. Di Santo, "Identification of committed NK cell progenitors in adult murine bone marrow," European Journal of Immunology, vol. 31, no. 6, pp. 1900-1909, 2001.

[60] S. Kim, K. Iizuka, H. S. P. Kang et al., "In vivo developmental stages in murine natural killer cell maturation," Nature Immunology, vol. 3, no. 6, pp. 523-528, 2002.

[61] C. A. J. Vosshenrich, T. Ranson, S. I. Samson et al., "Roles for common cytokine receptor $\gamma$-chain-dependent cytokines in the generation, differentiation, and maturation of NK cell precursors and peripheral NK cells in vivo," Journal of Immunology, vol. 174, no. 3, pp. 1213-1221, 2005.

[62] M. K. Kennedy, M. Glaccum, S. N. Brown et al., "Reversible defects in natural killer and memory CD8 T cell lineages in interleukin 15-deficient mice," Journal of Experimental Medicine, vol. 191, no. 5, pp. 771-780, 2000.

[63] G. M. Barton and A. Y. Rudensky, "An altered invariant chain protein with an antigenic peptide in place of CLIP forms SDS-stable complexes with class II $\alpha \beta$ dimers and facilitates highly efficient peptide loading," International Immunology, vol. 10, no. 8, pp. 1159-1165, 1998.

[64] H. D. Lacorazza, Y. Miyazaki, A. Di Cristofano et al., "The ETS protein MEF plays a critical role in perforin gene expression and the development of natural killer and NK-T cells," Immunity, vol. 17, no. 4, pp. 437-449, 2002.

[65] F. Colucci, S. I. Samson, R. P. DeKoter, O. Lantz, H. Singh, and J. P. Di Santo, "Differential requirement for the transcription factor PU.1 in the generation of natural killer cells versus B and T cells," Blood, vol. 97, no. 9, pp. 26252632, 2001.

[66] T. Ikawa, S. Fujimoto, H. Kawamoto, Y. Katsura, and Y. Yokota, "Commitment to natural killer cells requires the helix-loop-helix inhibitor ld2," Proceedings of the National Academy of Sciences of the United States of America, vol. 98, no. 9, pp. 5164-5169, 2001.

[67] W. Yan, A. Z. Young, V. C. Soares, R. Kelley, R. Benezra, and Y. Zhuang, "High incidence of T-cell tumors in E2A-null mice and E2A/Id1 double-knockout mice," Molecular and Cellular Biology, vol. 17, no. 12, pp. 7317-7327, 1997.

[68] C. Hacker, R. D. Kirsch, X. S. Ju et al., "Transcriptional profiling identifies Id 2 function in dendritic cell development," Nature Immunology, vol. 4, no. 4, pp. 380-386, 2003.

[69] M. A. Cannarile, N. A. Lind, R. Rivera et al., "Transcriptional regulator Id 2 mediates $\mathrm{CD}^{+} \mathrm{T}$ cell immunity," Nature Immunology, vol. 7, no. 12, pp. 1317-1325, 2006.

[70] I. Ueda-Hayakawa, J. Mahlios, and Y. Zhuang, "Id3 restricts the developmental potential of $\gamma \delta$ lineage during thymopoiesis," Journal of Immunology, vol. 182, no. 9, pp. 53065316, 2009.

[71] M. H. M. Heemskerk, B. Blom, G. Nolan et al., "Inhibition of $\mathrm{T}$ cell and promotion of natural killer cell development by the dominant negative helix loop helix factor Id3," Journal of Experimental Medicine, vol. 186, no. 9, pp. 1597-1602, 1997.

[72] K. Yun, A. Mantani, S. Garel, J. Rubenstein, and M. A. Israel, "Id4 regulates neural progenitor proliferation and differentiation in vivo," Development, vol. 131, no. 21, pp. 5441-5448, 2004.

[73] B. Cisse, M. L. Caton, M. Lehner et al., "Transcription factor E2-2 is an essential and specific regulator of plasmacytoid 
dendritic cell development," Cell, vol. 135, no. 1, pp. 37-48, 2008.

[74] R. Barndt, M. F. Dai, and Y. Zhuang, "A novel role for HEB downstream or parallel to the pre-TCR signaling pathway during $\alpha \beta$ thymopoiesis," Journal of Immunology, vol. 163, no. 6, pp. 3331-3343, 1999.

[75] Y. Zhuang, R. J. Barndt, L. Pan, R. Kelley, and M. Dai, "Functional replacement of the mouse E2A gene with a human HEB cDNA," Molecular and Cellular Biology, vol. 18, no. 6, pp. 3340-3349, 1998.

[76] T. Ikawa, H. Kawamoto, S. Fujimoto, and Y. Katsura, "Commitment of common T/natural killer (NK) progenitors to unipotent $\mathrm{T}$ and $\mathrm{NK}$ progenitors in the murine fetal thymus revealed by a single progenitor assay," Journal of Experimental Medicine, vol. 190, no. 11, pp. 1617-1625, 1999.

[77] R. Schotte, W. Dontje, M. Nagasawa et al., "Synergy between IL-15 and Id2 promotes the expansion of human NK progenitor cells, which can be counteracted by the E protein HEB required to drive T cell development," Journal of Immunology, vol. 184, no. 12, pp. 6670-6679, 2010.

[78] J. L. Matsuda, T. Mallevaey, J. Scott-Browne, and L. Gapin, "CD1d-restricted iNKT cells, the 'Swiss-Army knife' of the immune system," Current Opinion in Immunology, vol. 20, no. 3, pp. 358-368, 2008.

[79] J. L. Matsuda and L. Gapin, "Developmental program of mouse V $\alpha 14 \mathrm{i}$ NKT cells," Current Opinion in Immunology, vol. 17, no. 2, pp. 122-130, 2005.

[80] J. Rolf, E. Berntman, M. Stenström et al., "Molecular profiling reveals distinct functional attributes of CD1d-restricted natural killer (NK) T cell subsets," Molecular Immunology, vol. 45, no. 9, pp. 2607-2620, 2008.

[81] W. Barchet, M. Cella, B. Odermatt, C. Asselin-Paturel, M. Colonna, and U. Kalinke, "Virus-induced interferon $\alpha$ production by a dendritic cell subset in the absence of feedback signaling in vivo," Journal of Experimental Medicine, vol. 195, no. 4, pp. 507-516, 2002.

[82] W. Cao and Y. J. Liu, "Innate immune functions of plasmacytoid dendritic cells," Current Opinion in Immunology, vol. 19, no. 1, pp. 24-30, 2007.

[83] Y. Laouar, T. Welte, X. Y. Fu, and R. A. Flavell, "STAT3 Is Required for Flt3L-Dependent Dendritic Cell Differentiation," Immunity, vol. 19, no. 6, pp. 903-912, 2003.

[84] J. Aliberti, O. Schulz, D. J. Pennington et al., "Essential role for ICSBP in the in vivo development of murine CD8 $\alpha^{+}$ dendritic cells," Blood, vol. 101, no. 1, pp. 305-310, 2003.

[85] S. Suzuki, K. Honma, T. Matsuyama et al., "Critical roles of interferon regulatory factor 4 in $\mathrm{CD} 11 \mathrm{~b}^{\text {high }} \mathrm{CD} 8 \alpha^{--}$dendritic cell development," Proceedings of the National Academy of Sciences of the United States of America, vol. 101, no. 24, pp. 8981-8986, 2004.

[86] H. Tsujimura, T. Tamura, C. Gongora et al., "ICSBP/IRF-8 retrovirus transduction rescues dendritic cell development in vitro," Blood, vol. 101, no. 3, pp. 961-969, 2003.

[87] E. Ichikawa, S. Hida, Y. Omatsu et al., "Defective development of splenic and epidermal $\mathrm{CD}^{+}$dendritic cells in mice deficient for IFN regulatory factor-2," Proceedings of the National Academy of Sciences of the United States of America, vol. 101, no. 11, pp. 3909-3914, 2004.

[88] K. Honda, T. Mizutani, and T. Taniguchi, "Negative regulation of IFN- $\alpha / \beta$ signaling by IFN regulatory factor 2 for homeostatic development of dendritic cells," Proceedings of the National Academy of Sciences of the United States of America, vol. 101, no. 8, pp. 2416-2421, 2004.
[89] S. Carotta, A. Dakic, A. D’Amico et al., “The transcription factor PU.1 controls dendritic cell development and Flt3 cytokine receptor expression in a dose-dependent manner," Immunity, vol. 32, no. 5, pp. 628-641, 2010.

[90] A. D'Amico and LI. Wu, "The early progenitors of mouse dendritic cells and plasmacytoid predendritic cells are within the bone marrow hemopoietic precursors expressing Flt3," Journal of Experimental Medicine, vol. 198, no. 2, pp. 293303, 2003.

[91] N. Onai, A. Obata-Onai, M. A. Schmid, T. Ohteki, D. Jarrossay, and M. G. Manz, "Identification of clonogenic common $\mathrm{Flt}^{+} \mathrm{M}^{-} \mathrm{CSFR}^{+}$plasmacytoid and conventional dendritic cell progenitors in mouse bone marrow," Nature Immunology, vol. 8, no. 11, pp. 1207-1216, 2007.

[92] H. Karsunky, M. Merad, A. Cozzio, I. L. Weissman, and M. G. Manz, "Flt3 ligand regulates dendritic cell development from Flt $3^{+}$lymphoid and myeloid-committed progenitors to Flt3 ${ }^{+}$ dendritic cells in vivo," Journal of Experimental Medicine, vol. 198, no. 2, pp. 305-313, 2003.

[93] S. H. Naik, P. Sathe, H. Y. Park et al., "Development of plasmacytoid and conventional dendritic cell subtypes from single precursor cells derived in vitro and in vivo," Nature Immunology, vol. 8, no. 11, pp. 1217-1226, 2007.

[94] R. Schotte, M. Nagasawa, K. Weijer, H. Spits, and B. Blom, "The ETS transcription factor Spi-B is required for human plasmacytoid dendritic cell development," Journal of Experimental Medicine, vol. 200, no. 11, pp. 1503-1509, 2004.

[95] M. Nagasawa, H. Schmidlin, M. G. Hazekamp, R. Schotte, and B. Blom, "Development of human plasmacytoid dendritic cells depends on the combined action of the basic helixloop-helix factor E2-2 and the Ets factor Spi-B," European Journal of Immunology, vol. 38, no. 9, pp. 2389-2400, 2008.

[96] H. Spits, F. Couwenberg, A. Q. Bakker, K. Weijer, and C. H. Uittenbogaart, "Id2 and Id3 inhibit development of CD34 stem cells into predendritic cell (pre-DC)2 but not into preDC1: evidence for a lymphoid origin of pre-DC2," Journal of Experimental Medicine, vol. 192, no. 12, pp. 1775-1783, 2000.

[97] B. T. Edelson, K. C. Wumesh, R. Juang et al., "Peripheral $\mathrm{CD}_{103^{+}}$dendritic cells form a unified subset developmentally related to $\mathrm{CD} 8 \alpha^{+}$conventional dendritic cells," Journal of Experimental Medicine, vol. 207, no. 4, pp. 823-836, 2010.

[98] A. Kallies, E. D. Hawkins, G. T. Belz et al., "Transcriptional repressor Blimp-1 is essential for T cell homeostasis and selftolerance," Nature Immunology, vol. 7, no. 5, pp. 466-474, 2006.

[99] A. M. Intlekofer, N. Takemoto, E. J. Wherry et al., "Effector and memory $\mathrm{CD}^{+} \mathrm{T}$ cell fate coupled by T-bet and eomesodermin," Nature Immunology, vol. 6, no. 12, pp. 1236-1244, 2005.

[100] H. Ichii, A. Sakamoto, M. Hatano et al., "Role for BcL-6 in the generation and maintenance of memory $\mathrm{CD}^{+} \mathrm{T}$ cells," Nature Immunology, vol. 3, no. 6, pp. 558-563, 2002.

[101] J. M. Angelosanto and E. J. Wherry, "Transcription factor regulation of $\mathrm{CD}^{+}$T-cell memory and exhaustion," Immunological Reviews, vol. 236, no. 1, pp. 167-175, 2010.

[102] G. T. Belz and A. Kallies, "Effector and memory CD8 ${ }^{+} \mathrm{T}$ cell differentiation: toward a molecular understanding of fate determination," Current Opinion in Immunology, vol. 22, no. 3, pp. 279-285, 2010.

[103] K. M. Murphy and B. Stockinger, "Effector T cell plasticity: flexibility in the face of changing circumstances," Nature Immunology, vol. 11, no. 8, pp. 674-680, 2010.

[104] T. Kusunoki, M. Sugai, T. Katakai et al., "TH2 dominance and defective development of a $\mathrm{CD}^{+}$dendritic cell subset in 
Id2-deficient mice," Journal of Allergy and Clinical Immunology, vol. 111, no. 1, pp. 136-142, 2003.

[105] A. Iavarone, E. R. King, X.-M. Dai, G. Leone, E. R. Stanley, and A. Lasorella, "Retinoblastoma promotes definitive erythropoiesis by repressing Id 2 in fetal liver macrophages," Nature, vol. 432, no. 7020, pp. 1040-1045, 2004.

[106] S. Mori, S. I. Nishikawa, and Y. Yokota, "Lactation defect in mice lacking the helix-loop-helix inhibitor Id2," The EMBO Journal, vol. 19, no. 21, pp. 5772-5781, 2000.

[107] F. Sablitzky, A. Moore, M. Bromley, R. W. Deed, J. S. Newton, and J. D. Norton, "Stage- and subcellular-specific expression of Id proteins in male germ and Sertoli cells implicates distinctive regulatory roles for Id proteins during meiosis, spermatogenesis, and Sertoli cell function," Cell Growth and Differentiation, vol. 9, no. 12, pp. 1015-1024, 1998.

[108] E. L. Rawlins, C. P. Clark, Y. Xue, and B. L. M. Hogan, "The Id $2^{+}$distal tip lung epithelium contains individual multipotent embryonic progenitor cells," Development, vol. 136, no. 22, pp. 3741-3745, 2009. 


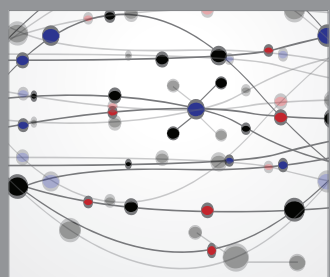

The Scientific World Journal
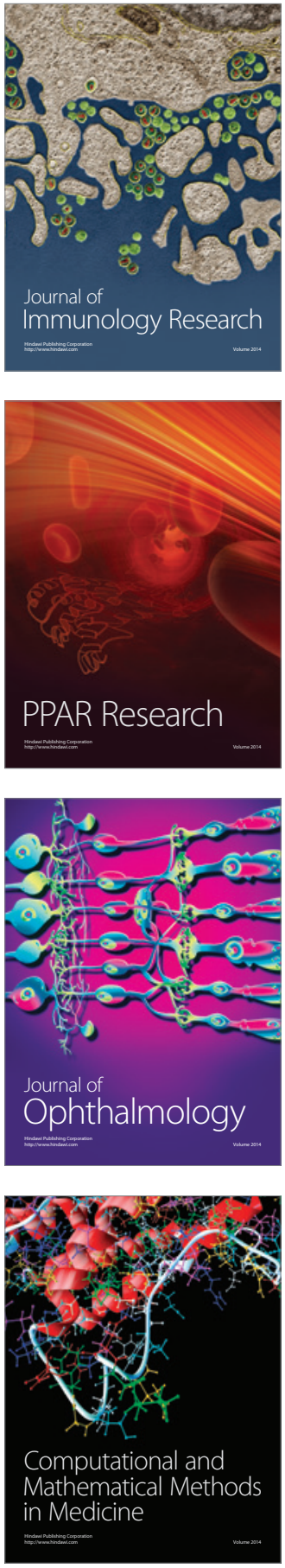

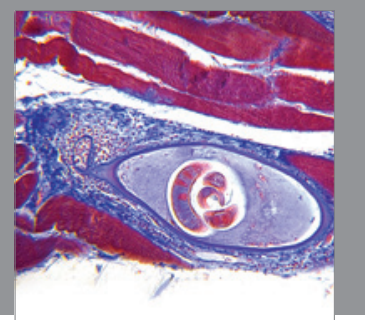

Gastroenterology

Research and Practice
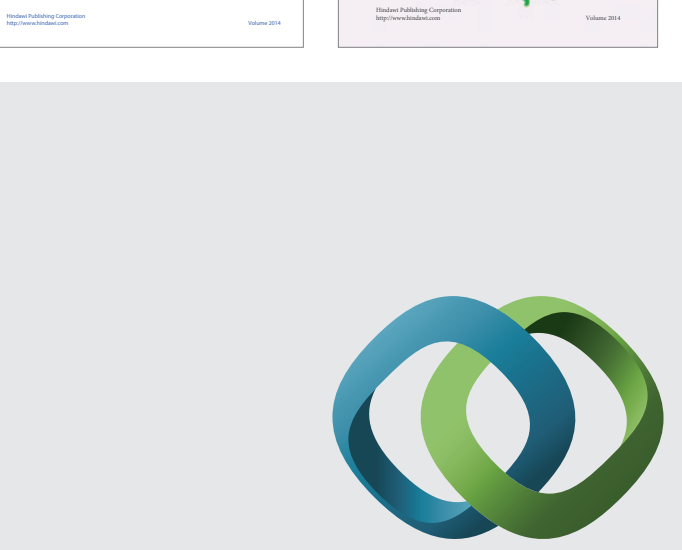

\section{Hindawi}

Submit your manuscripts at

http://www.hindawi.com
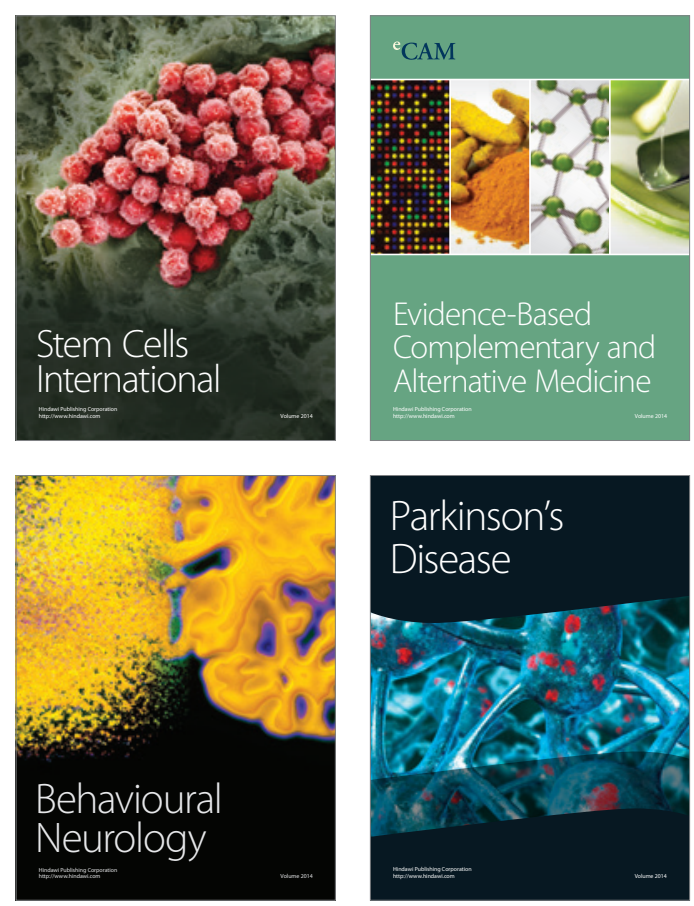

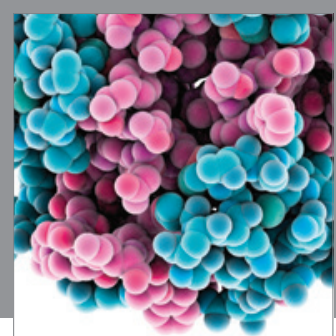

Journal of
Diabetes Research

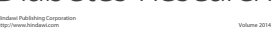

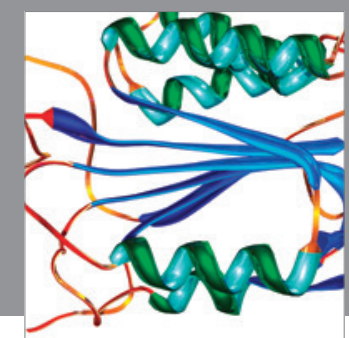

Disease Markers
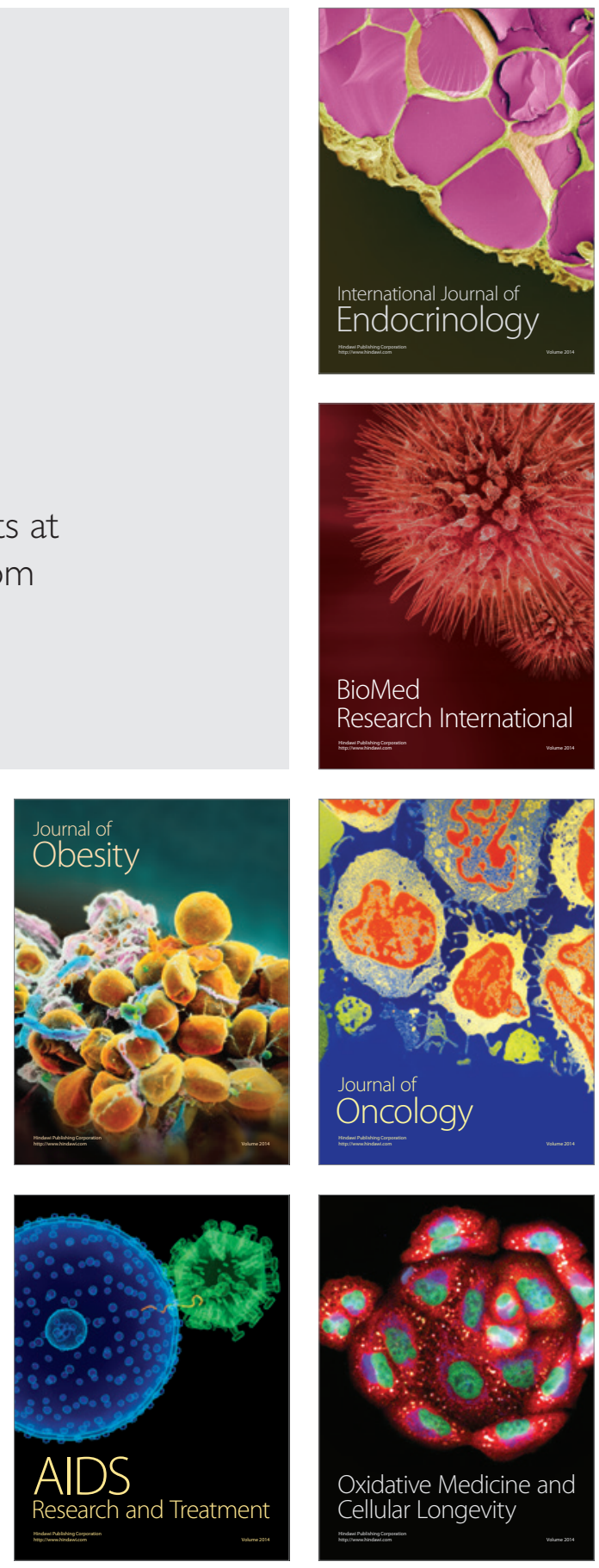